Brit. J. industr. Med., 1954, 11, 126.

\title{
INDIVIDUAL DIFFERENCES IN ACCIDENT SUSCEPTIBILITY AMONG COAL MINERS
}

\author{
BY \\ J. W. WHITFIELD \\ From the Psychological Laboratory, University College, London
}

(RECEIVED FOR PUBLICATION OCTOBER 31, 1953)

\begin{abstract}
DESCRIPTION AND SOURCE OF DATA
A system for recording and describing underground accidents was introduced at a group of collieries in the Nottinghamshire coalfield in April, 1944. Three months were spent in a trial period to eliminate working problems and to enable the foremen, safety-officers, labour department, and others concerned to become familiar with the system. The records proper began on July 1, 1944. At the same time, detailed working records were taken from one colliery in the group. These working records were produced weekly, and showed for each man his place(s) of work, his occupation(s), and the number of shifts worked in each occupation in each place. The data had been collected for the calculation of wages and cost analysis. In January, 1947 , the costing classification was changed. This meant either working with the two-and-a-half-year observational period then complete, or attempting to match data from two classifications to use a longer period. The additional labour and possibility of error if the latter course were attempted probably would outweigh the increase in information gained from a longer period of study. Thus the data used in this investigation were obtained in the period July, 1944, to December, 1946, inclusive.
\end{abstract}

\section{Working Environment and the Occupations}

The colliery from which these records were taken is moderately large, having about 2,000 men on its books. The nearest village is about 1 mile away and is predominantly rural. Unlike many collieries it does not have a mining village of its own. The men come partly from the industrial areas of a large town, about 4 miles away, and partly from nearby villages. As the two seams worked are at moderate depth and both are dry, no temperature or humidity problems need be considered. The seams differ; one is hard coal, varying in thickness between $2 \mathrm{ft} .6 \mathrm{in}$. and $3 \mathrm{ft}$., with a firm stone floor and roof, requiring heavy props and bars. The other is a much softer coal, varying between $3 \mathrm{ft}$. $3 \mathrm{in}$. and $3 \mathrm{ft} .9$ in., with a relatively soft and shaly roof. Both seams were worked (during the period concerned) on the longwall advancing method. The cycle of operations and the occupations involved may be briefly summarized.

The longwall or "face" of coal has three approaches ("gates"), one at each end and one in the middle. The face is first undercut from end to end to a predetermined depth by a cutting machine, operated by machinemen. At the same time the two conveyor belts (which run parallel to the face, one from each end to the middle) are dismantled and moved nearer to the face to be in position for the next loading shift. This movement of the conveyors is performed by flitters. The two belts converge on to a shorter belt, running at right-angles out towards the main roadway (the gate-end loader). This requires greater height than the seam itself allows, and also, it is placed in what will become part of the main road as the face advances. Gaining this extra height by digging into the "floor" and removing part of the " roof" is the work of rippers, who also install the girders of the roadways.

As the face is advancing at the rate of one machine cut per day, the space left behind after the coal has been removed is an important consideration. Near to the existing face this space is preserved by means of steel props and bars which prevent lowering or falls of the roof or the floor rising. (Under mining conditions earth can roughly be considered as a viscous fluid, and any disturbance will slowly be filled in from all sides.) Further back from the working space the steel props are replaced by "packs", mounds and walls of stone and rubble, 
which give gently under the pressure of floor and roof. In due time these packs are compressed to the limit and the space previously occupied by coal has virtually ceased to exist. The rate of closure is important to the working of the face. If it proceeds too rapidly the strain on the roof may prove too great, causing major falls of roof. If too slowly, there is insufficient pressure on the coal at the face, and instead of the undercut coal being partially forced off the face by the roof pressure the full labour of prising it out of the solid is left to the collier. The men who build the packs and remove the props and bars are called packers.

After these preparatory operations the face is ready for the coal-getting shift. Shot holes are drilled by borers and charged and exploded by shotfirers. The coal is broken off the face, broken up, shovelled or lifted on to the conveyor belt by the collier. $\mathrm{He}$ also puts up the props and bars as he reaches the uncut coal behind. The coal goes along the conveyor, on to the gate-end loader and is tipped into the mine-cars (tubs), which have been manhandled into position by the loader. A train of tubs is coupled up, clipped on to the endless steel rope, unclipped and reclipped at junctions by haulage hands. At the bottom of the shaft they are unclipped, uncoupled, and put on to the cage (either by pushing, gravity, or mechanical aid) by the pit-bottom staff.

During the course of the investigation there was a steady change towards the use of main road conveyors instead of tubs. These main conveyors loaded into heavier mine cars near the pit bottom.

Work at the face is supervised, and the roof and propping examined, by the overman or his deputy. The main roads and haulage tracks are extended and kept in good condition by rippers and repairers. Maintenance and advancement of electrical equipment is the work of underground electricians. The few pit ponies which remain for odd haulage tasks are in the charge of horsekeepers.

Individual men work mainly at one occupation for some reasonable length of time, but intermittent changes are frequent, the overman booking his men to their jobs according to necessity. Temporary changes of working place are also frequent, and over the course of a few weeks a man may work at three or four occupations in as many or more working places.

\section{Accident Records}

The accident classification used for this investigation has subsequently been condensed and modified in some points to become the current Non-Fatal Accident Return Under Coal Mines Act (Ministry of Fuel and Power M.D. Return 39). The data are, therefore, presented in this latter form as an Appendix in Tables A, B, C, and D. The entries are for " compensation" accidents only. Nominally these are accidents which have prevented a man from earning his full wages at his normal work for a period of more than three days, but there are $4.2 \%$ of cases for which absence is reported as three days or less. These men may have returned to surface or light work only, or there may be errors in the records. Table 1 gives the median absence for different occupations.

TABLE 1

NUMBER OF ACCIDENTS AND MEDIAN ABSENCE

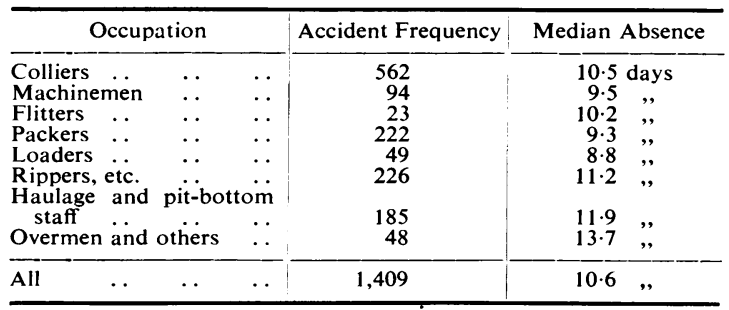

\section{COMPARISON OF INDIVIDUALS}

To compare individuals on their accident experience it is necessary to have a common unit of measurement. For example, it is impossible to make direct comparison between a collier who has had three accidents in two and a half years and a haulage hand who has had one accident in two years. Some account has to be taken of the differences in objective or inherent risk between the two occupations. In the original studies of accident proneness by Greenwood and Woods (1919) this problem was avoided to a large extent by working with large groups of individuals who were assumed to be exposed to the same risk by virtue of the same number of days worked in the same occupation in the same factory building. To avoid complications caused by absence from work due to accident injury, only minor injuries, not involving absence, were studied.

This procedure raises some practical objections. The use of minor injury data can be criticized. An assumption that major and minor injury accidents are highly correlated in the sense that an individual who has a lot of minor accidents is also likely to have a lot of major accidents has not been verified. It seems likely that the correlation, though positive, is low. A more basic objection lies in the conclusion to be drawn when the Poisson distribution does not fit the data. "Proneness to report a minor injury" is as valid a conclusion as "proneness to 
experience a minor injury". This objection cannot be wholly overcome in any kind of survey. Whatever the definition of accident (except fatality), there is a margin within which the individual himself decides whether or not he has sustained an "accident". If we take as "accidents" those occasions when absence from work is attributable to accident injury, the willingness or unwillingness of the individual to absent himself is a margin of error. For the main purpose of this study an " accident" was defined as an accident which resulted in injury sufficient to warrant compensation. To some extent the onus was, therefore, on the medical officers of the compensation department, working within the prescriptions of the Workmens Compensation Act. There is no doubt that some of the same type of variation persists, but this criterion was adopted as being perhaps the most standard and objective criterion possible under the circumstances. It has also the merit of being easily understood within industry, and the data can readily be collected as part of the existing requirements for the statutory returns.

As men in a coal-mine work in different occupations, in various parts of the colliery, and for varying periods, an assumption of equal risk over equal periods is untenable, and a comparative measure has to be found. For this, the risk per shift for moderately homogeneous working groups was found. Two main sources of heterogeneity were considered; occupation and place of work. Although underground occupations are somewhat specialized it was possible to produce reasonably homogeneous occupation groups. Grouping was necessary for two reasons. Statistically the errors of small samples would outweigh the apparent increase in accuracy provided by fine divisions, and secondly there were enormous practical advantages to be gained by accepting existing classifications, even though these had been designed for other purposes.

The following occupation classification was used : (1) Colliers, including borers; (2) machinemen ; (3) packers, flitters, loaders, rippers, repairers ; (4) haulage and pit-bottom staff; (5) deputies, overmen, shotfirers, horsekeepers, underground electricians.

Groups 3 and 5 are the least homogeneous. Group 5 consists of a number of different occupations with comparatively few men in each. Group 3 includes more men, but the detailed classification of occupation in the accident returns did not match that of the cost analysis in any finer division.

Place of work was classified primarily into seam. In the case of colliers it was possible further to sub-divide into "districts", either individual coal faces or two or three faces close together.

Given the number of accidents occurring in each occupation-place category, and the number of manshifts for the same, it was possible to calculate the risk for that occupation in that place. This was done for all occupation-place categories, giving a series of risks per shift. It was then assumed that an individual's risk, for example as a machineman in No. 1 seam, was the number of shifts he had worked there as a machineman multiplied by the risk per shift for machinemen in No. 1 seam, established as described. Therefore, each man's working. record for the period was taken, and the number of shifts he had worked as a collier in each place, as a machineman, as a packer or flitter, etc., were computed. From the rates per man-shift his risk in each category was determined. His total risk (i.e., his expected number of accidents) together with his actual accident history provides the basis for comparing him with other individuals.

There are some possible objections to this. It takes no account of change in risk due to change in working conditions over the period. It has also been shown that under certain conditions, such as length of shift, the simple arithmetical relationship between time and risk does not hold. This could possibly be true for longer time units, i.e., an individual who habitually works six shifts a week may be be exposing himself in comparison with an individual who consistently works five shifts more than a six-to-five ratio would indicate. To calculate this effect and allow for it would be very laborious. As it happens, in this study there is some evidence that individuals who sustain relatively many accidents work fewer shifts per week than the others. It is debatable whether an individual characteristic such as weekly working habit, or age, or experience should be taken into account at this stage, or whether they should instead be considered as possible factors making for individual difference in accident susceptibility.

A considerable number of men worked for short periods only during the observational period and, therefore, had only low total accident risks. This was in part due to the "Optant" and "Bevin Boy" schemes which were in force for part of the period. It was decided to exclude from further study all whose risk was lower than 0.300.* Table 2 shows the risk and accident distribution for the remainder.

The observed frequency of accidents in each

* This necessitated a slight modification of the calculated risk
values. 
TABLE 2

DISTRIBUTION OF ACCIDENTS AND RISK

\begin{tabular}{|c|c|c|c|c|c|c|c|c|c|c|c|c|}
\hline \multirow{2}{*}{\multicolumn{3}{|c|}{ Risk }} & \multicolumn{10}{|c|}{$\begin{array}{l}\text { No. of Individuals having Given } \\
\text { No. of Accidents }\end{array}$} \\
\hline & & & 0 & 1 & 2 & 3 & 4 & 5 & 6 & 17 & 7 & 8 \\
\hline $\begin{array}{l}0 \cdot 300-0.499 \\
0 \cdot 500-0.699 \\
0 \cdot 700-0.899 \\
0.900-1.099 \\
1 \cdot 100-1 \cdot 299 \\
1 \cdot 300-1.499 \\
1 \cdot 500-1.699 \\
1 \cdot 700-1.899 \\
1 \cdot 900-2.099 \\
2 \cdot 100-2.299 \\
2 \cdot 300-2.499 \\
2 \cdot 500-2.699\end{array}$ & $\begin{array}{l}\cdots \\
\cdots \\
\cdots \\
\cdots \\
\cdots \\
\cdots \\
\cdots \\
\cdots \\
\cdots\end{array}$ & $\begin{array}{l}\ldots \\
\cdots \\
\cdots \\
\cdots \\
\cdots \\
\cdots \\
\cdots \\
\cdots\end{array}$ & $\begin{array}{r}141 \\
123 \\
127 \\
113 \\
50 \\
27 \\
27 \\
22 \\
5 \\
3 \\
1 \\
1\end{array}$ & $\begin{array}{r}74 \\
76 \\
76 \\
80 \\
31 \\
30 \\
30 \\
14 \\
8 \\
1 \\
1 \\
1\end{array}$ & $\begin{array}{r}20 \\
26 \\
39 \\
44 \\
31 \\
12 \\
17 \\
3 \\
5 \\
1\end{array}$ & $\begin{array}{r}9 \\
8 \\
20 \\
12 \\
5 \\
11 \\
7 \\
5 \\
2 \\
1\end{array}$ & $\begin{array}{l}1 \\
4 \\
8 \\
3 \\
4 \\
4 \\
3 \\
1\end{array}$ & $\begin{array}{l}3 \\
1 \\
1\end{array}$ & $\begin{array}{l}2 \\
1 \\
1 \\
1\end{array}$ & & 1 & 1 \\
\hline Total & $\ldots$ & $\ldots$ & 640 & 421 & 198 & 80 & 28 & 9 & 6 & & 1 & 1 \\
\hline
\end{tabular}

risk group does not correspond to that expected on risk and number of men, although the totals agree with a small error attributable to grouping. Table 3 shows that this is a systematic discrepancy.

TABLE 3

SYSTEMATIC DISCREPANCY BETWEEN NUMBER OF ACCIDENTS EXPECTED AND OBSERVED*

\begin{tabular}{|c|c|c|c|c|c|}
\hline Risk & & $\begin{array}{c}\text { No. of } \\
\text { Individuals }\end{array}$ & $\begin{array}{l}\text { Observed } \\
\text { Accident } \\
\text { Frequency }\end{array}$ & $\begin{array}{l}\text { Expected } \\
\text { Accident } \\
\text { Frequency }\end{array}$ & $\begin{array}{l}\text { Observed- } \\
\text { Expected }\end{array}$ \\
\hline $\begin{array}{l}0 \cdot 300-0 \cdot 499 \\
0 \cdot 500-0 \cdot 699 \\
0 \cdot 700-0 \cdot 899 \\
0 \cdot 900-1 \cdot 099 \\
1 \cdot 100-1 \cdot 299 \\
1 \cdot 300-1.499 \\
1 \cdot 500-1 \cdot 699 \\
1 \cdot 700-1 \cdot 899 \\
1 \cdot 900-2 \cdot 099 \\
2 \cdot 100-2 \cdot 299 \\
\text { Over } 2 \cdot 299\end{array}$ & $\begin{array}{l}\cdots \\
\cdots \\
\cdots \\
\cdots \\
\cdots \\
\cdots \\
\cdots \\
\cdots\end{array}$ & $\begin{array}{r}245 \\
241 \\
271 \\
255 \\
118 \\
86 \\
88 \\
49 \\
22 \\
6 \\
3\end{array}$ & $\begin{array}{r}145 \\
189 \\
251 \\
233 \\
114 \\
116 \\
120 \\
57 \\
33 \\
6 \\
1\end{array}$ & $\begin{array}{r}97 \cdot 88 \\
144 \cdot 48 \\
216 \cdot 66 \\
254 \cdot 87 \\
141 \cdot 54 \\
120 \cdot 36 \\
140 \cdot 76 \\
88 \cdot 18 \\
43.99 \\
13 \cdot 20 \\
7.60\end{array}$ & $\begin{array}{l}+47.12 \\
+44.52 \\
+34.34 \\
-21.87 \\
-27.54 \\
-4.36 \\
-20.76 \\
-31 \cdot 18 \\
-10.99 \\
-7.20 \\
-6.60\end{array}$ \\
\hline Totals & . & 1,384 & 1,265 & $1,269 \cdot 52$ & -4.52 \\
\hline
\end{tabular}

* The small overall discrepancy is due to the grouping of the data.

Chi squared is 75.52 , and with 11 degrees of freedom (as the grand totals do not agree exactly) this gives a probability of less than 0.0001 .

The first hypothesis which must be considered to account for this is that if a man has an accident he is absent from work. His risk, based on the number of shifts worked, will be lower than that of an otherwise comparable man who has not had an accident. Therefore, it might be thought that those men who had many accidents would "drift" down into the lower risk categories by virtue solely of their absence. If the absence were long enough this would certainly produce the effect noticed. But this does not seem to be the case. The median absence per accident for the groups of risk 0.300-0.499 and $0.500-0.699$ is 10.9 days. This corresponds approximately to an arithmetical average of 13.9 working days. This loss of working days would correspond to a reduction of calculated risk by 0.0467 per accident in the case of colliers, who have a relatively high risk. Thus in the $0.300-0.499$ risk group a total expectation of 6.77 accidents may be considered lost in this way. As the actual discrepancy is $47 \cdot 12$, some other cause must be assumed to operate. In addition, the effect is actually overestimated in this simple approach ; it cannot be assumed that had there been no absence there would have been no additional accident during the period.

A second possibility is that the low-risk groups contain a higher proportion of individuals who first began underground work during the observational period, and that the discrepancy is due to their inexperience. This is not borne out by the relationship of age to accident history ; the younger men, a large proportion of whom are new to the industry, do not show such an increase in incidence over expectation.

A third hypothesis is that there is a relationship between accident proneness and attendance at work. The working records for a period of 20 weeks were studied for three samples of men. The samples were extracted for the observations described in the detailed study of selected individuals and consist of $(+)$ men who had many more accidents than their calculated risk; $(=)$ men who had approximately the same accident history as their calculated risk ; $(-)$ men with no, or at most one, accident and a high calculated risk. For this attendance study the full samples were used, except for one $(-)$ individual who was absent for the whole of the 20 -week period (Table 4 ).

TABLE 4

DISTRIBUTION OF SHIFTS WORKED PER WEEK IN THREE SAMPLES* (in \%)

\begin{tabular}{c|r|r|r}
\hline No. of Shifts Worked in Week & $(+)$ & $(=)$ & $(-)$ \\
\hline 0 & 10.78 & 3.06 & 2.93 \\
1 & 2.19 & 0.81 & 0.69 \\
2 & 2.66 & 1.94 & 2.07 \\
3 & 9.84 & 6.45 & 5.69 \\
4 & 15.78 & 13.55 & 12.93 \\
5 & 23.91 & 28.87 & 22.41 \\
6 & 30.62 & 32.58 & 38.79 \\
7 & 3.91 & 10.48 & 10.52 \\
8 & 0.31 & 2.26 & 3.97 \\
\hline Mean number of shifts worked in week & 4.33 & 5.10 & 5.24 \\
\hline
\end{tabular}

* 20-week period February 1-June 21, 1946.

The $(+)$ group worked significantly fewer shifts per week than the others. There is the possibility that this is an artifact of the sampling procedure. The $(-)$ group, in particular, is drawn from men who have a high calculated risk and who, therefore, must have worked a great deal. But this is not 
necessarily true of the $(=)$ group. The $(+)$ group comes from men with a low calculated risk, who must have worked less than most during the observational period. But if this were due to accident absence, or to having begun underground work during the observational period, then while they were available for work there should be no difference between them and the others in respect of attendance. If it can be taken, as is intended, that the $(+)$ group is a representative sample of accident-prone individuals, a general relationship between accident proneness and short-week working can be suggested. The problem will be discussed later on.

Although the term "accident-proneness" has been introduced, it is not very easy to demonstrate its existence in a clear-cut statistical fashion. The systematic discrepancy between the expectation based on risk, and the observed accident frequency discussed above means a choice of assumptions on which chance distributions are to be based. Three chance distributions have been calculated and $\chi^{2}$ tests of goodness of fit applied. The distributions

from the comparison of individuals are therefore : (1) There are more multi-accident individuals than would be expected on the assumption of equal liability. (2) These multi-accident individuals tend to have been exposed to a comparatively low risk of accident. The evidence is suggestive that they are irregular in their attendance at work.

\section{THE RELATION OF AGE TO ACCIDENT RISK}

The data were analysed into five-year age groups, within each of which the total number of accidents and the total calculated risk were found for each of the occupation groups. These are shown in Table 6.

In considering these observations two points must be borne in mind. The first is that differences in age may be related to differences in actual work. This is particularly to be expected in team occupations, where the youngest are probably acting as assistants, those somewhat older taking the main burden, and the older men directing and supervising the work. The second is concerned with selection effects. The older men in the more strenuous occupations are generally the more physically fit members

TABLE 5

$\chi^{2}$ VALUES OF GOODNESS OF FIT OF THREE DISTRIBUTIONS

\begin{tabular}{|c|c|c|c|c|c|c|c|c|c|}
\hline \multirow{2}{*}{$\begin{array}{l}\text { Calculated } \\
\text { Risk Group }\end{array}$} & \multicolumn{3}{|c|}{ (a) } & \multicolumn{3}{|c|}{ (b) } & \multicolumn{3}{|c|}{ (c) } \\
\hline & $x^{2}$ & d.f. & $\mathbf{P}$ & $\chi^{2}$ & d.f. & $\mathbf{P}$ & $x^{2}$ & d.f. & $\mathbf{P}$ \\
\hline $\begin{array}{l}0 \cdot 3- \\
0 \cdot 5- \\
0 \cdot 7- \\
0.9- \\
1 \cdot 1- \\
1 \cdot 3- \\
1 \cdot 5- \\
1.7- \\
1 \cdot 9-\end{array}$ & $\begin{array}{r}18.97 \\
20.09 \\
25.44 \\
6.43 \\
14.90 \\
5.80 \\
7.67 \\
32.46 \\
9.26\end{array}$ & $\begin{array}{l}2 \\
3 \\
3 \\
3 \\
3 \\
3 \\
3 \\
3 \\
2\end{array}$ & $\begin{array}{l}0.0001 \\
0.001 \\
0.0001 \\
0.1 \\
0.01 \\
0.2 \\
0.1 \\
0.0001 \\
0.01\end{array}$ & $\begin{array}{r}5 \cdot 16 \\
6 \cdot 72 \\
16 \cdot 69 \\
3 \cdot 22 \\
9 \cdot 78 \\
5 \cdot 42 \\
1.65 \\
12.62 \\
1.69\end{array}$ & $\begin{array}{l}2 \\
2 \\
2 \\
2 \\
2 \\
2 \\
2 \\
2 \\
2\end{array}$ & $\begin{array}{l}0 \cdot 1 \\
0 \cdot 05 \\
0 \cdot 001 \\
0 \cdot 2 \\
0 \cdot 01 \\
0 \cdot 1 \\
0 \cdot 5 \\
0 \cdot 01 \\
0 \cdot 5\end{array}$ & $\begin{array}{r}0.61 \\
2.99 \\
2.02 \\
1.70 \\
10.43 \\
1.94 \\
1.16 \\
3.67 \\
0.01\end{array}$ & $\begin{array}{l}1 \\
1 \\
1 \\
1 \\
1 \\
1 \\
1 \\
1 \\
1\end{array}$ & $\begin{array}{l}0.4 \\
0.08 \\
0.16 \\
0.19 \\
0.0013 \\
0.16 \\
0.28 \\
0.06 \\
0.91\end{array}$ \\
\hline Totals & 141.02 & 25 & 0.0001 & 62.95 & 18 & 0.0001 & $24 \cdot 53$ & 9 & 0.01 \\
\hline
\end{tabular}

are: (a) Poisson distributions based on mean calculated risk in each risk group. (b) Poisson distributions based on actual mean accident rate for each risk group. The assumption, therefore, is that the systematic discrepancy is evenly distributed amongst individuals, and that the observed means are true measures of risk. (c) Yule's negative binomial, based on observed means and variances.

It will be seen that $(a)$ does not fit at all, $(b)$ is slightly better, and that $(c)$ fits quite well, the only odd value occurring in the 1.1-1.299 risk group (Table 5). (Fuller tables are available on application to the author.)

Thus we can say that even within the risk groups and even eliminating the overall discrepancy from consideration, an assumption of equal liability amongst individuals does not hold. The conclusions of their age group. These points make it difficult to generalize about the relation of age to accident

TABLE 6

OBSERVED AND EXPECTED NUMBER OF ACCIDENTS BY AGE

\begin{tabular}{|c|c|c|c|c|c|c|c|c|c|c|}
\hline \multirow{2}{*}{$\begin{array}{c}\text { Age on } \\
1.1 .46\end{array}$} & \multicolumn{2}{|c|}{ Colliers } & \multicolumn{2}{|c|}{$\begin{array}{c}\text { Machine- } \\
\text { men }\end{array}$} & \multicolumn{2}{|c|}{$\begin{array}{l}\text { Rippers, } \\
\text { etc. }\end{array}$} & \multicolumn{2}{|c|}{ Haulage } & \multicolumn{2}{|c|}{$\begin{array}{l}\text { Overmen, } \\
\text { etc. }\end{array}$} \\
\hline & O & $\mathbf{E}$ & $\mathbf{O}$ & $\mathbf{E}$ & $\mathbf{O}$ & $\mathbf{E}$ & $\mathbf{O}$ & $\mathbf{E}$ & O & $\mathrm{E}$ \\
\hline $\begin{array}{l}-22 \\
23-27 \\
28-32 \\
33-37 \\
38-42 \\
43-47 \\
48-52 \\
53-57 \\
58+\end{array}$ & \begin{tabular}{|r}
113 \\
66 \\
42 \\
49 \\
93 \\
65 \\
63 \\
22 \\
19
\end{tabular} & $\begin{array}{r}107.4 \\
56.5 \\
44.5 \\
54.5 \\
94.5 \\
77.9 \\
57.0 \\
23.3 \\
15.8\end{array}$ & $\begin{array}{r}2 \\
8 \\
9 \\
5 \\
34 \\
17 \\
2 \\
5 \\
7\end{array}$ & $\begin{array}{r}6 \cdot 1 \\
8 \cdot 8 \\
6 \cdot 8 \\
7 \cdot 7 \\
26 \cdot 3 \\
24 \cdot 2 \\
1 \cdot 3 \\
3 \cdot 4 \\
4 \cdot 6\end{array}$ & $\begin{array}{r}41 \\
25 \\
24 \\
59 \\
108 \\
50 \\
59 \\
50 \\
42\end{array}$ & $\begin{array}{l}77 \cdot 9 \\
25 \cdot 9 \\
28 \cdot 8 \\
49 \cdot 2 \\
90 \cdot 3 \\
55 \cdot 3 \\
44 \cdot 4 \\
34 \cdot 6 \\
51 \cdot 5\end{array}$ & $\begin{array}{r}55 \\
11 \\
10 \\
15 \\
16 \\
9 \\
8 \\
9 \\
8\end{array}$ & $\begin{array}{r}40 \cdot 6 \\
14 \cdot 5 \\
8 \cdot 3 \\
14 \cdot 1 \\
20 \cdot 7 \\
10 \cdot 6 \\
13.7 \\
7 \cdot 5 \\
11 \cdot 1\end{array}$ & $\begin{array}{r}1 \\
2 \\
2 \\
3 \\
3 \\
15 \\
7 \\
6 \\
6\end{array}$ & $\begin{array}{r}5.0 \\
3.9 \\
2.4 \\
5.5 \\
4.8 \\
10.0 \\
6.0 \\
3.4 \\
4.9\end{array}$ \\
\hline Totals & 532 & 531.4 & 89 & $89 \cdot 2$ & 458 & 457.9 & 141 & $141 \cdot 1$ & 45 & 45.9 \\
\hline
\end{tabular}

$O=$ Observed frequency. $\quad E=$ Expected frequency. 
susceptibility and the observations are descriptive only.

The relationship may be studied in each occupation. For colliers there is little evidence of any relationship, except for a slight superfluity of observed accidents with the young and the old. In actual practice it is likely that the difference in real risk is considerably more than is shown here, for two reasons, both concerned with the working arrangements of the colliery. Young men are trained as colliers on special training faces until they are judged competent for normal face work. On these training faces the amount of coal to be loaded is less than on the full working face, and only the fit men proceed rapidly through the training faces to full work. Thus both environment and selection are at work to reduce the risk of the younger men. Up to a point the environmental difference is taken care of in the calculation of risk. (Individual faces were used where possible to provide the basis for the calculation of colliers' risk.) At these training faces a number of older men are also employed, particularly the steady workers whose example of good working method is valuable instruction for the trainees. And as only the fit older men continue to work as colliers, it would appear also likely that the effect of age on accident liability is obscured for the older men as well. These points, or their presumed effects, are conjecture, but it seems possible that in the statistically ideal condition of equal sampling and objectively equal exposure the effects of inexperience and age would be much more marked.

Machinemen work as a team, and the relation of age to accident liability is most likely to be derived from the relationship of age to specific occupation in the team.

As mentioned earlier, the rippers, repairers, etc., group is not very homogeneous. Age is likely to be related to actual differences in work.

Haulage involves a lot of very young and inexperienced men, and the less fit members of other age groups. As far as the younger men are concerned, it is usually their first occupation underground, and it is reasonable to suggest that their relatively high accident incidence is due to inexperience, to the specific nature of their work, and also to general conditions underground.

\section{FAMILY RELATIONSHIP AND ACCIDENT RISK}

Mining is still to some extent a family occupation. At this colliery there were a number of family groups working. Two relationships were studied: father and son, and brothers.

There were 50 fathers with a total of 61 sons working in the mine. To obtain a comparative measure the following transformation was adopted. Each individual was given a percentile rank as to his standing on accident history related to his exposure. A Poisson distribution of accidents was assumed; e.g., if an individual had one accident and a calculated risk of $0 \cdot 800$, we would expect $19 \%$ of the population to have more than one accident with this risk, and $36 \%$ to have one accident only. Thus the percentile standing of this individual is $19+18=37$, which is the percentage of the population expected to be worse than he is.

There is little overall relationship, but a breakdown of the data in Table 7 shows that accidentfree fathers tend to have accident-free sons.

TABLE 7

ACCIDENT LIABILITY OF FATHËRS AND SONS

\begin{tabular}{c|c|c|c}
\hline $\begin{array}{c}\text { Percentile Grade } \\
\text { of Father }\end{array}$ & $\begin{array}{c}\text { No. of Fathers } \\
\text { in Grade }\end{array}$ & $\begin{array}{c}\text { Mean Grade of } \\
\text { Sons of these } \\
\text { Fathers }\end{array}$ & No. of Sons \\
\hline $0-24$ & 14 & $45 \cdot 33$ & 21 \\
$25-74$ & 23 & 52.71 & 24 \\
$75-99$ & 13 & 66.50 & 16 \\
\hline
\end{tabular}

There were 86 families of brothers comprising 189 individuals. There was no relationship in accident liability.

These samples are incomplete if we wish to consider the possibility that differences in accident liability are inherited. Some sons or brothers may have left the industry, or may be working in other collieries. It is possible that such self-selection might be related to accident proneness. A man whose father is accident prone may decide more readily against working in a mine than one whose father is comparatively free from accident. This does not seem likely from the sample, as the relatively accident-prone fathers have the highest proportion of sons in the mine. From the point of view of simple inheritance we would expect a similar relationship to exist between brothers as between fathers and sons, and it is not easy to see how any selection effect could alter one relationship without disturbing the other. As the only significant relationship is that the sons of the 75-99 percentile fathers are freer from accidents than the others (Student $t=$ $2 \cdot 22$ ), it would appear more likely that the accidentfree fathers train their sons in good working practices, either directly or by advice and explanation.

\section{DETAILED STUDY OF SELECTED INDIVIDUALS}

Studies of the personal qualities associated with accident proneness have usually taken the form of measurement or appraisal, over a large sample, 
of those qualities considered relevant. The measures have then been correlated with subsequent accident histories. This method has two valuable characteristics ; (1) it is concerned with predisposition, and post-accident effects can be disregarded, and (2) assuming the sample to be random for the population in or entering the industry, the degree of relationship shown between the qualities and accident proneness can be considered as measured for the relevant population as a whole. At the same time this method has a major disadvantage. A large sample is required, partly because of the Poisson-like distribution of accidents, and partly to cover loss through retirement or change of work during the follow-up period. A large sample imposes severe practical limitations on the amount of information it. is possible to obtain about each individual.

An alternative approach was used in this investigation. Three comparatively small samples of men were chosen on a basis of their known accident history. The observation period was the two-and-ahalf year period referred to earlier. One sample was composed of men who had experienced many more accidents than their calculated risk warranted. These are called the $(+)$ or accident-prone group. Each individual in this group was matched with two other men in respect of age and normal mining occupation. In a few cases the matching is approximate only. These two other men represented two other types of accident experience. One had experienced about as many accidents as would be expected from his calculated risk, an accident-average or $(=)$ man, the other had been remarkably free from accident, and accident-free or (-) man. One triad may serve as an example.

The triads were examined by Dr. D. Russell Davis, Dr. R. B. Buzzard, Mr. I. Gordon Brown, Mr. H. Letty, Mr. J. Spencer, and myself (I wish here to express my indebtedness to my colleagues). Dr. Russell Davis's special interests in the investigation have been published (1949). The members of the team were aware that each triad consisted of a $(+),(=)$, and $(-)$ individual but, with the exception of myself, they did not know which was which. To maintain this freedom from bias I confined myself to those measurements which were free from subjective judgment.

Thirty-three triads were arranged, the first to act purely as a trial run for testing the experimental procedures and timing the programme. The remaining 32 triads divided themselves fairly conveniently into four age groups. The age is given as at January $1,1948$.

\begin{tabular}{c|c|c|c}
\hline Group & No. of Triads & $\begin{array}{c}\text { Range of } \\
\text { Average Age }\end{array}$ & $\begin{array}{c}\text { Individual Age } \\
\text { Range }\end{array}$ \\
\hline A & 7 & $22-25$ & $27-20$ \\
B & 12 & $34-44$ & $45-33$ \\
C & 8 & $47-50$ & $51-42$ \\
D & 5 & $55-64$ & $66-53$ \\
\hline
\end{tabular}

The overlap in individual ages between $B$ and $C$ is confined to two cases, one each way, and is caused by the difficulty of matching occupations as well as ages.

Six subjects did not appear, leaving a total of 90 individuals. The failures were : $(1)(+)$, age group D, (2) (=), age groups A and B, (3) (-), two age group $\mathrm{A}$ and one age group $\mathrm{C}$. The standing of the samples on a Poisson percentile, calculated as on page 131 is shown in Table 8 :

TABLE 8

MEAN PERCENTILE STANDING OF SAMPLES

\begin{tabular}{c|c|c|c}
\hline Group & $(+)$ & $(=)$ & $(-)$ \\
\hline-3 & 7.0 & 51.8 & 86.2 \\
B & 2.6 & 48.0 & 86.3 \\
C & 2.8 & 48.9 & 87.3 \\
D & 9.0 & 50.0 & 88.6 \\
\hline
\end{tabular}

Thus the samples can be held to represent the extremes and the middle of the population from which they were drawn.

As the observational period was relatively brief, and in view of the suggestion by Johnson and Cobb (1938) and Johnson (1946) that there is comparatively little correlation in accident proneness over successive observation periods, it seemed necessary to consider whether these samples were representative in a wider sense, i.e., that the accidentprone individuals were persistently so and not merely individuals who had " struck a bad patch"

\begin{tabular}{|c|c|c|c|c|c|c|c|c|c|c|c|c|c|c|}
\hline \multirow{2}{*}{$\begin{array}{c}\text { Triad } \\
\text { No. }\end{array}$} & \multirow{2}{*}{$\begin{array}{c}\text { Accident } \\
\text { Class }\end{array}$} & \multirow{2}{*}{$\begin{array}{l}\text { Year of } \\
\text { Birth }\end{array}$} & \multicolumn{6}{|c|}{ Expected No. of Accidents (by occupation groups) } & \multicolumn{6}{|c|}{ Accidents } \\
\hline & & & $\mathbf{C}$ & $\mathbf{M}$ & PR & $\mathbf{H}$ & 0 & Total & $\mathbf{C}$ & $\mathbf{M}$ & PR & $\mathbf{H}$ & $\mathbf{O}$ & Total \\
\hline \multirow{3}{*}{2} & + & 1924 & 0.604 & 0.020 & & & & 0.624 & 5 & & & & & 5 \\
\hline & $=$ & 1927 & 1.041 & 0.011 & $0 \cdot 156$ & 0.098 & 0.001 & $1 \cdot 307$ & & & & 1 & & 1 \\
\hline & - & 1925 & 0.944 & & 0.092 & 0.087 & & $1 \cdot 123$ & & & & & & 0 \\
\hline
\end{tabular}

$\mathbf{C}=$ collier, $\mathbf{M}=$ machineman, $\mathbf{P R}=$ packer and ripper, $\mathbf{H}=$ haulage hand, $\mathbf{O}=$ overman. 
coincidental with the period of observation. A post hoc enquiry was made a year after the investigation. The records could not be treated in detail in that calculated risk could not be measured in any real sense. A few individuals had left the colliery and their records were not available. Taking as a crude measure accident rate per month of exposure (neglecting actual attendance or occupation, although the latter can be assumed to be fairly well balanced for the samples) the following was observed (Table 9).

\section{TABLE 9}

ACCIDENT RATES PER MONTH FOR SAMPLES BEFORE AND AFTER OBSERVATION PERIOD

\begin{tabular}{|c|c|c|c|c|c|}
\hline & $\begin{array}{c}1938 \text { and } \\
1939\end{array}$ & $\begin{array}{l}1940 \text { and } \\
1941\end{array}$ & $\begin{array}{l}1942 \text { and } \\
1943\end{array}$ & $\begin{array}{c}1944 \text { (to } 30 \cdot 6) \\
\text { and } 1947\end{array}$ & All \\
\hline $\begin{array}{l}(-) \\
(=) \\
(-)\end{array}$ & $\begin{array}{l}0.0263 \\
0.0175 \\
0.0100\end{array}$ & $\begin{array}{l}0.0470 \\
0.0280 \\
0.0270\end{array}$ & $\begin{array}{l}0.0593 \\
0.0500 \\
0.0297\end{array}$ & $\begin{array}{l}0.0472 \\
0.0261 \\
0.0292\end{array}$ & $\begin{array}{l}0.0458 \\
0.0315 \\
0.0238\end{array}$ \\
\hline
\end{tabular}

The overall differences are significant. As they are based on very crude measures they imply that the samples chosen are representative for a period considerably greater than the observational period.

\section{Measures Used and Design of the Investigation}

No overriding theory governed the selection of measures used in this enquiry. As the number of individuals studied was small, and the time available with each correspondingly large (about five hours), it was felt that all measures could be used which might reasonably be assumed to relate to the problem on psychological grounds, although the previous work by Farmer, Chambers, and Kirk (1933) to some (xtent dominated the choice of measures. Some measures which might have proved desirable, such as a standard intelligence test, were omitted on practical grounds. The measures used fall into the following groups.

Acuities.-A miner works in dim illumination, and often with a background of considerable noise. (It is commonly held that changes in the creaking of the roof and supports are an important sign of danger from falls of roof.) Therefore, visual and auditory acuities were measured. Visual acuity was measured by Snellen cards, four of which were used, the first presented in daylight, the others presented after five, 15, and 30 minutes of adaptation to dim light, approximately that cast by an ordinary miner's lamp. Differential auditory acuity was measured by subjecting the individual to a fixed intensity of sound, and introducing known intensities of sound of different frequency. (The apparatus was designed and built by Dr. A. Carpenter.)

Medical History and Present Medical State.-This was aimed at determining the extent to which physical or medical disability was responsible for accident proneness.
Interview.-The interview was concerned with the attitude to work, domestic and other environmental circumstances, and an assessment of the amount and direction of the individual's activity.

The medical and interview data proved to be valuable background material, but except for a few specific instances it was not possible adequately to codify them into any reasonable statistical classification. However, as the number of individuals studied was small the various details thrown up from these sources were valuable, in retrospect, to the members of the team, and contributed greatly to the interpretation of the more easily systematized data.

Performance Tests of Perceptual, Cognitive, and Memory Functions.-Test 28, originally devised by Bartlett, involves mainly spatial perception and memory.

Test 28.-A display is given with four columns and seven rows with a symbol, word, or representative drawing in each cell. It is shown for $\mathbf{3 0}$ seconds and then replaced by a similar display in which some of the symbols, etc., have changed position. The subject enters on a proforma whether in each cell the entry is the same as before, different, in the sense that the symbol was previously somewhere else in the display, or whether the symbol is a new one altogether. There is a time limit of two minutes. The second display is then removed and the subject enters on a second proforma the entries cell by cell for the original display (two minutes' time limit). Scoring is the number correct in both cases.

The Rey-Davis Test.-This has been described by Zangwill (1946). Four squares of wood, each with nine knobs, are arranged to form a large square. In each small square one knob is free to move, the others are fixed. The subject begins at the top left small square and discovers by trial and error which is the free knob. He then goes to the next square clockwise and does the same, continuing round and round until he has learned which is the free knob in each square (five consecutive correct trials being the criterion of learning). The whole square is then rotated ninety degrees clockwise and the subject relearns. The number of errors is taken as the score.

Matching.-This test was devised for the investigation. It consists of six photographs of underground mining operations. These were cut into two, along the N.E.-S.W. diagonal. To make matching less a process of immediate perception, and more a task involving judgment and interpretation of the material, a strip of the photograph along the diagonal was obscured. This provided a gap, which the subject had mentally to jump in his perception. The top portions were fixed on a large sheet, and the six bottom parts were shuffled and handed to the subject A specimen photograph (not one of the six) was demon. strated to the subject to show him how the pieces matched and to draw his attention to clues provided by continuity of scene over the gap. The subject was then asked to match the six bottom pieces against their appropriate tops, two minutes being allowed. They were then shown which matches were correct and which 
incorrect, appropriately marked cards being placed against the photographs as well as verbal indication given. The subject was allowed to look at this without manipulating it in any way for half a minute. The bottom pieces were removed, shuffled, and the subject made a second attempt, one and a half minutes being allowed. The procedure was repeated for four trials or until perfect matching was obtained. Scoring was on the basis of information gained (Whitfield, 1951).

Directions Test.-Ten directions test questions were read to the subjects, with one minute in which to write the answer to each. This test was not standardized until the tenth triad.

Motor Control and Coordination.-Two performance tests were used.

Craik Triple Tester.-This is a tracking task; the subject uses a wheel to control the position of a pointer, with the aim of making as many contacts with irregular dots on a moving display as possible. Two conditions were used, one with little foreknowledge of the track ahead, and the other with greater visibility ahead but an indirect velocity control through an integrating disc. One preliminary trial was allowed in each condition.

Davis Controlled Response Test (Davis, 1949).--The subject controls a pointer through a velocity control actuated by a wheel at the subject's left hand. The pointer has to be moved to the central, left, or right settings on the receipt of light signals. In some instances the signals are ambiguous. A continuous record of wheel movement is made. Several quantitative measures were attempted (reaction time, extent of movement, overshooting, undershooting, reversals, etc.), but it was discovered that they did not adequately describe the differences between the records. The complete traces were then rated on overall performance by an assessor, who was kept unaware of the identity of each record.

\section{Statistical Treatment of Data*}

Some of the data were expressed in quantitative terms (e.g., number of contacts made with the triple tester), some as ratings (as in the interview and the controlled response test), and some as order of merit. The quantitative measures cannot be assumed to be distributed normally. It is obviously convenient to use a single measure of relationship throughout, and so all measures were expressed as order of merit. The best performance is ranked 1 , the worst 90 . The relation between performance and accident proneness is expressed as a Kendall $\tau$ correlation, comparing the ranks assigned to the $(+)$ with those assigned to the $(=)$ and $(-)$ groups combined. Hence a positive value means that the $(+)$ group performed better than the others. In each case the significance is tested as described by Whitfield (1947). It is worth mentioning that $\tau$ is numerically smaller than the equivalent product moment correlation, but a product moment correlation would not be valid for samples of this nature.

\footnotetext{
* Full details of observations are available on request.
}

Where the observations permitted good discrimination (as in the performance tests) the data were analysed separately for the four age groups. Where the measures were relatively crude classifications (as in the interview and medical data) the age groups were condensed into $(\mathrm{A}+\mathrm{B})$ and $(\mathrm{C}+\mathrm{D})$. The correlations are given in Table 10. The probability values quoted are for the magnitude of the correlation, irrespective of sign.

TABLE 10

SUMMARY OF CORRELATION VALUES COMPARING ACCIDENT GROUP WITH OTHERS

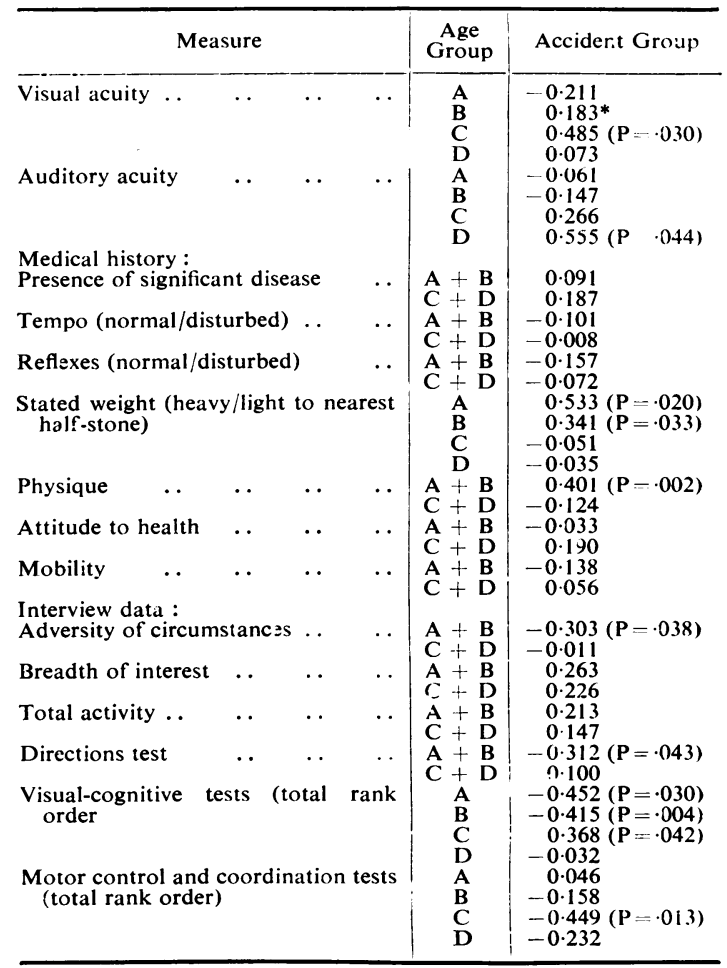

* A positive value mears that the accident group performed better than the non-accident groups.

\section{Results of Observations and Tests}

Acuities.-These show little relationship with accident proneness and the slight indication is contrary to expectation. This does not mean that defect of vision or hearing is necessarily without effect, but it does imply that variation of acuity within the normal (sample) range is of no predictive value for accident proneness. Two cases only of gross defect were observed. One with markedly poor vision was a collier, aged 50 at the time of the investigation and with an accident-free history. The other was a packer and ripper, aged 25 , accident average, who suffered from middle-ear defect. 
Medical History and Present Medical State.-As mentioned earlier, this largely provided background information, not easily expressible in quantitative terms. The two significant relationships observed are unexpected and interesting. The younger accident-prone men (groups A and B) are heavier than their contemporaries and were judged to be of superior physique.

One case of gross restriction of movement was observed, a collier aged 52, whose right elbow articulation was restricted to about 30 degrees, as a result of a childhood fracture being badly set. $\mathrm{He}$ was in the accident-average category, and it is interesting to consider that in spite of this severe restriction of movement he should have proved able to cope with the heavy lifting and shovelling work for so long. One marked post-accident disability case was discovered. A packer-ripper, aged 58, had, before the observation period, received severe head injuries, with considerable loss of intellectual function. The clinical picture was somewhat confused by chronic alcoholism. This man was free from accident during the observational period, but there is some justification for suspecting that this was due to comparative inaction.

Interview Data.-Again this mainly provided background material; the specific questions for the interviewer's judgment did not show much relationship with accident proneness, with the exception of "adversity of circumstances". Younger accident-prone men show greater adversity, judged by their accounts of upbringing, early life, and present state.

Perceptual-Cognitive Tests.-These show a wellmarked relationship. Younger accident-prone men are markedly deficient in these groups of measures (with which we can associate the Direction Test). Older accident-prone men show no such deficiency; in the $\mathrm{C}$ age group they show significant superiority.

Motor Control and Coordination.-There is little relationship in the younger age group with these measures, but the older accident-prone are markedly deficient.

Thus overall it appears that accident proneness is related to the measures in the following way. Younger accident-prone men tend to be heavy, with powerful physique, with little or no impairment of motor control or coordination, but they give markedly poor performances on tests involving perceptual, memory, and cognitive processes.

Older accident-prone men are average or above average in the perceptual and cognitive tasks, but considerably inferior in motor control and coordination.

\section{DISCUSSION}

It seems fairly clear from the survey data that there exist individual differences in accident susceptibility amongst coal miners. Further, it appears that these statistical differences cannot readily be attributable to differences in age, and the study of family relationship does not suggest any simple form of inheritance. The main bulk of the evidence on the nature of accident proneness comes from the study of the selected samples. It now remains to consider whether this evidence can be put together to form a coherent picture of accident proneness, from which specific and testable hypotheses may be drawn.

If an accident is considered as a failure to make an adequate response to a hazardous situation, such failure could arise from failure in either or both of two constituent processes. There may be (a) failure to appreciate the demands of the situation, a failure of the individual to perceive the hazard or to decide what, if any, response ought to be made, or $(b)$ there may be failure adequately to produce the appropriate response, even though the hazard has been perceived and an appropriate course of action initiated. The accident-prone individual may, therefore, be considered as an individual who habitually fails in either or both of these respects.

The two sources of failure, $(a)$ appreciation and (b) performance, can be expected to be demonstrated in the two groups of psychological tests used. Failures of appreciation ought to be shown in poor scores on the visual-cognitive group of tests and performance failures in poor scores on the motor control and coordination tests. The observations in this study agree with this; the accident-prone individuals give poor scores on one or the other of the test groups. There is also a strong indication that the type of failure associated with accident proneness differs with age. Putting the conclusions in their simplest form, young accident-prone men show failure of a perceptual and cognitive nature, without any defect in the response mechanism; older accident-prone men show failure to produce an adequate response, although it appears likely that their perceptual and cognitive ability is normal.

This raises a new problem and there are several choices of argument. One possibility is that both types of accident proneness exist independently of age, and that the observed age difference is a sampling artifact. This could come about by means of a change in the type of person recruited to the industry over the past 30 years. Or, alternatively, 
the type of accident-prone person characteristic of the younger age groups may leave the industry, thus allowing only the other type of accident proneness to be demonstrated in the older age groups. These are possibilities which cannot be excluded completely. The second could be verified by a study of "leavers", particularly those with a multiaccident history, and by studying the early accident histories of the known older accident prone.

But if the sampling possibilities are discounted there still remains a major choice of argument. Either accident proneness is not a persistent characteristic of the individual, or else the perceptual, cognitive, and motor abilities measured in the enquiry are not relatively stable, in the sense that an individual does not maintain his position with respect to his contemporaries. It is usually considered that these performance measures are moderately stable for the individual, and failing direct evidence the remainder of the argument is based on the assumption that they are This view is somewhat strengthened by the data on weight and physique, where there are marked differences between the younger and older accident-prone men.

One feature common to both young and old accident prone, and which is possibly a counter argument against this assumption, is their working fewer shifts in a sample period than the others. While this is a common feature if overall averages are used, an alternative measure of number of weeks with the full six shifts or more shows that the younger men work significantly fewer such weeks, whereas the older men do not differ significantly. The difference, however, is not very great, and it appears that short-time working is a feature of accident proneness per se rather than the prerogative of one of the postulated types.

Let us consider first the older accident prone, the man who has normal or good perceptual and cognitive ability, but whose motor control is below normal. As a young man he was probably able to cope with most situations, his anticipation of events enabling him to respond well within the limits of his motor ability. As he grows older, slowly his motor ability deteriorates (not necessarily more rapidly than in other individuals), his reaction time increases. There may also be some deterioration in perceptual and cognitive ability. The stage is reached when an appreciable number of situations, with which he previously could have coped adequately are now just about the limit or beyond the limit of his combined perceptual and motor ability. This is likely to be a slow process, and it is not likely that he is aware of it, or sufficiently aware to modify his working behaviour. It is more likely that he persists in his usual work and usual methods of work and becomes accident prone without knowing anything about such change. It may be suggested that this process might account for the observation, frequently made by factory and mine managements, that some of the safest men might get killed.

The converse problem, why the younger accidentprone men. apparently cease to be so, is less easy to explain. It may be that they leave the industry - as is suggested above. However, some of the test evidence suggests a similarity between the young accident prone and the older accident free. Post-hoc discussion with the interviewer gave rise to the observation that some of the older accident-free men "looked like young accident-prone men who had worn themselves out". This is very slender evidence, but it is perhaps worth speculating that the active carelessness (lack of foresight, appreciation of the situation, etc.), characteristic of the young accident prone can be replaced by a passive carelessness. Some of the older accident-free men gave the impression at interview that they were accident free largely by virtue of decreased activity and hence decreased risk, unassessable in terms of shifts worked. The suggestion of a change from active to passive carelessness is unverified, and is not a satisfactory psychological description. Much more evidence is needed, first to demonstrate whether such a change takes place, and secondly to define the process in more acceptable psychological terms.

Failing such evidence, the observations can only be expressed as hypotheses, which can be restated : (i) Accident proneness is a behavioural symptom of either (a) deficiency of perceptual or cognitive ability, or (b) deficiency in motor ability. (ii) These deficiencies become apparent in accident proneness at different ages. Perceptual and cognitive deficiency makes itself shown with younger men, and motor ability deficiency in older men. (iii) Perceptual and cognitive deficiency, if associated with marked activity, are shown in accident proneness; but reduced activity may give a spurious indication of accident safeness. (iv) The individual who is deficient in motor ability compensates for this by anticipation, but this compensation is of steadily decreasing adequacy as age increases.

\section{CONCLUSIONS}

The conclusions drawn from one experiment only may not be valid, and the primary hypotheses developed in this study should be tested. Samples of accident-prone individuals of different ages should be examined to see whether the relationships 
indicated are capable of generalization. Such an investigation should aim at closer delimitation of the age range in which the transition between the two types of accident proneness takes place. If the transition is demonstrated, and its age range measured, the next stage would be to study more closely the development of the "older type" of accident proneness. The practical aim would be to determine methods whereby the older accidentprone man could be detected sufficiently early and protected. The social loss caused by injury to the older men is very great, both in terms of their domestic commitments, which are probably greater and less flexible than those of younger men, and also from the point of view of the industry in respect of the wide mining skill they have attained.

The problem of the younger accident prone is more difficult. If, as the interview data suggest, adversity of circumstances, particularly in youth, is a predisposing quality, this is not susceptible to direct action by the industry. Nor would their rejection by the industry be satisfactory policy. It would seem that the only way of tackling the problem is by training. It may be impossible to teach caution to a happy-go-lucky, careless person, but specific working methods, appropriate to their lack of foresight, could be worked out and taught. An awareness of safety officers and instructors that good motor coordination is not, by itself, an indication of freedom from accident risk would be of value to this end.

\section{SUMMARY}

Disabling accidents were studied at one colliery from July 1, 1944, to December 31, 1946 . Individuals who worked for brief periods only were excluded, leaving 1,384 miners with 1,265 accidents. An actuarial risk was calculated for each man, based on the number of shifts worked, place of work, and occupation. Discrepancies between calculated risk and actual accident experience were analysed, and accident proneness demonstrated.

Accident proneness was related to age, family relationship, and physical and psychological characteristics. Differences were found between the younger and older accident prone ; in particular, the younger accident prone showed deficiencies in perception and cognition, whereas the older accident prone were deficient in motor response performance.

This work would not have been possible without the help of many people. In addition to those who took part in the study of individual cases, the writer wishes to thank Mr. E. Farmer, Reader in Industrial Psychology in the University of Cambridge ; Mrs. D. Collins, of the Applied Psychology Research Unit, Cambridge; the management and staff of B.A. Collieries, Ltd., particularly Mr. O. B. Lewis and Mr. G. P. Thompson, and the men who subjected themselves to examination. The writer also wishes to thank the Medical Research Council for their support, and Professor Sir Frederic Bartlett for his constant encouragement.

\section{REFERENCES}

Davis, D. R. (1949). Ouart. J. exp. Psychol., 1, 136.

-, Farmer, E., and Chambers, E. G. (1929). Rep. industr. Hlth Res. Board Lond., No. 55

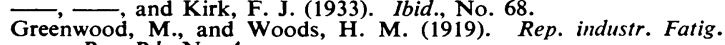
Res. Bd., No. 4.

Johnson, H. M. (1946). Psychol. Bull., 43, 6.

Whitfield, J. W. (1947). (1938). Ibid., 35, 758.

- (1951). Quart. J. exp. Psychol., 3, 184.

Zangwill, O. L. (1946). J. ment. Sci., 92, 19. 
TABLE A

ACCIDENTS CLASSIFIED IN OCCUPATIONS* AND OPERATIONS

\begin{tabular}{|c|c|c|c|c|c|c|c|c|c|}
\hline & C & $\mathbf{M}$ & $\mathbf{F}$ & $\mathbf{P}$ & L & $\mathbf{R}$ & H & O & Total \\
\hline vel, ring- & 214 & 17 & 2 & 13 & & 83 & 3 & 1 & \\
\hline 2. Usi & & - & - & 1 & - & - & - & - & 2 \\
\hline - Colle & & - & - & & & & - & - & \\
\hline acks $\because \cdots$ & - & - & - & 54 & - & 7 & - & 1 & 62 \\
\hline $\begin{array}{l}\text { 5. Ere } \\
\text { 6. Set }\end{array}$ & - & & - & - & - & & & - & \\
\hline & 62 & 3 & 9 & 88 & 2 & 31 & 6 & 3 & 204 \\
\hline $\begin{array}{l}\text { 7. Layi } \\
\text { ha }\end{array}$ & & & & & & 2 & & - & 8 \\
\hline $\begin{array}{l}\text { A8. Loading by hand on to } \\
\text { face conveyor.. }\end{array}$ & & & & & & & & & $21+2>+$ \\
\hline B1. Driving or servicing cut- & & & & & & & & & \\
\hline B2. Dri & & & & & & & & & \\
\hline 33. Serv & - & - & - & - & - & - & 1 & 1 & \\
\hline & 7 & - & 5 & 8 & 7 & 3 & 3 & 3 & 36 \\
\hline $\begin{aligned} \text { zate-end } \\
. .\end{aligned}$ & - & - & - & - & 7 & - & 5 & - & 12 \\
\hline ring machine.. & 3 & 1 & - & - & - & & - & 2 & \\
\hline ver mach- & - & - & - & - & - & 1 & - & - & 1 \\
\hline . & - & - & - & - & - & - & - & 1 & 1 \\
\hline $\begin{array}{l}\text { Coupling or uncoupling } \\
\text { tubs }\end{array}$ & - & - & - & & - & 1 & 23 & - & 26 \\
\hline & 1 & - & & - & 1 & & 28 & - & 34 \\
\hline $\begin{array}{l}\text { D3. Lockering or spra } \\
\text { D4. Pushing tubs on }\end{array}$ & 1 & - & - & - & 1 & & 14 & - & 17 \\
\hline . Oth & 二 & 二 & 二 & 二 & -7 & -6 & $\begin{array}{r}3 \\
44\end{array}$ & -2 & $\begin{array}{r}3 \\
59\end{array}$ \\
\hline 1. Tra & 27 & 4 & 1 & 12 & 3 & 14 & 5 & 13 & 79 \\
\hline E3. Chargin & & & & & & & & & \\
\hline 4. Shelte & 9 & 1 & 二 & 2 & 二 & $=$ & $=$ & 1 & 13 \\
\hline and unl & & & & & & & & & \\
\hline & 30 & 3 & 1 & 10 & 3 & 22 & 14 & - & 83 \\
\hline $\begin{array}{l}\text { 8. Clea } \\
\text { ing }\end{array}$ & & & & & & & & & \\
\hline & - & - & - & - & - & - & - & & \\
\hline sufficient detail & 178 & $\overline{18}$ & 2 & 31 & 11 & 38 & 30 & & 316 \\
\hline Total & 562 & 94 & & 222 & 492 & 226 & 185 & 48 & 1,409 \\
\hline
\end{tabular}

The occupation is that for which the man was booked on the day of the accident, and does not take into account the odd half hour changes of work which sometimes havpen. e.g., a haulage hand would not normally be driving or servicing a cutter machine, but one may have been available when an extra man was required, and in so working he received an injury.
TABLE B

OBJECTS INVOLVED AND INTERVENING CAUSES

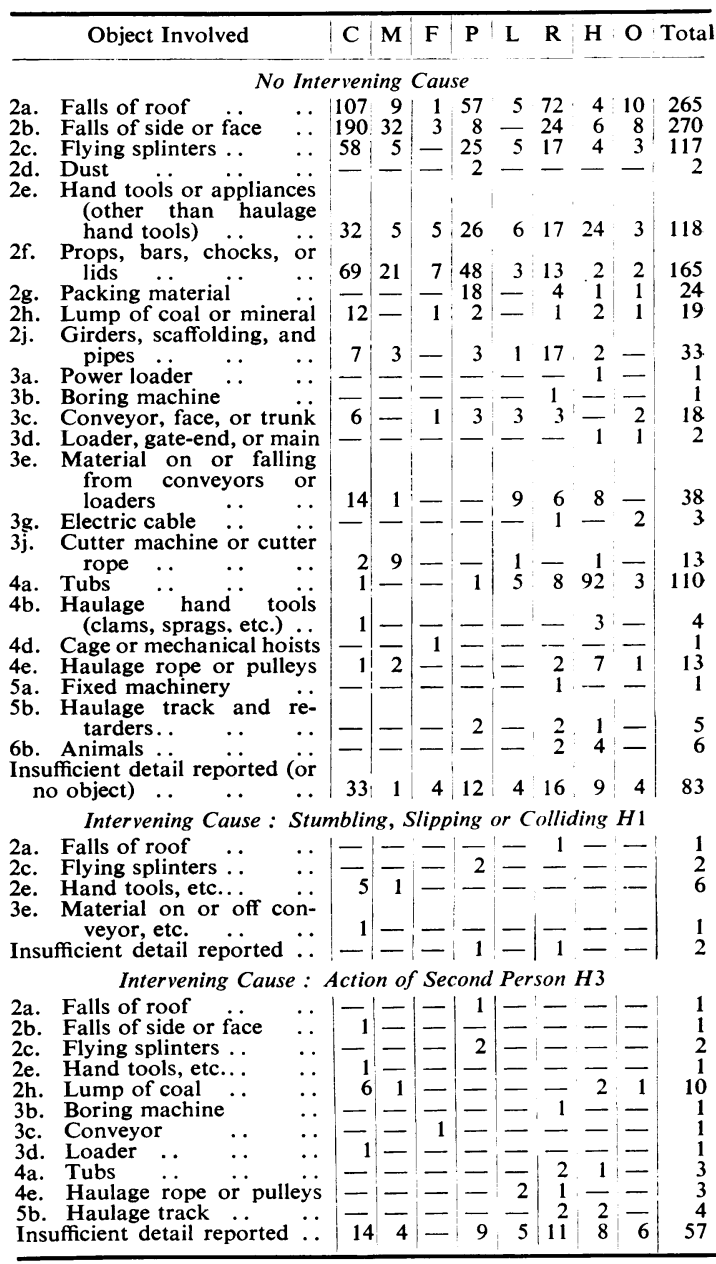

* $\mathbf{C}=$ colliers, $\mathbf{M}=$ machinemen, $\mathbf{F}=$ flitters, $\mathbf{P}=$ packers, $\mathbf{L}==$ loaders, $\mathbf{R}=$ rippers and repairers, $\mathbf{H}=$ haulage and pit-bottom staff, $\mathrm{O}=$ overmen, deputies, shotfirers, horsekeepers, stonedusters, underground electricians. 
TABLE C

NATURE OF INJURY

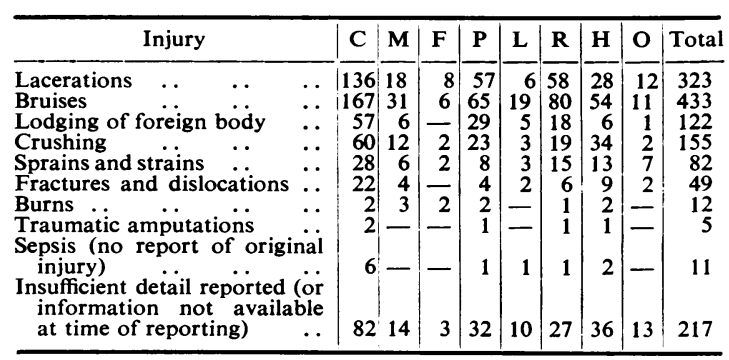

* $\mathrm{C}=$ colliers, $\quad \mathbf{M}=$ machinemen, $\quad \mathrm{F}=$ flitters, $\quad \mathbf{P}=$ packers, $\mathbf{L}=$ loaders. $\mathbf{R}=$ rippers and repairers, $\mathbf{H}=$ haulage and pitbottom staff, $\mathrm{O}=$ overmen, deputies, shotfirers, horsekeepers, stonedusters, underground electricians.
TABle D

SITE OF INJURY

\begin{tabular}{|c|c|c|c|c|c|c|c|c|c|c|c|c|}
\hline & & & & C & $\mathbf{M}$ & $\mathbf{F}$ & $\mathbf{P}$ & L & $\mathbf{R}$ & $\mathbf{H}$ & O & Total \\
\hline Head & & & & & 2 & - & 8 & 1 & & & & 44 \\
\hline .. & & .. & & & 1 & - & 6 & - & 2 & 1 & 2 & \\
\hline$\therefore$ & & .. & • & & $\tau_{0}$ & - & & - & 2 & 1 & - & 6 \\
\hline & & . & . & 6 & 8 & - & 29 & 6 & 19 & 4 & 1 & 127 \\
\hline Back and sp & pine & .. & .. & 4 & 5 & 2 & 21 & 4 & 13 & 9 & 8 & 109 \\
\hline Ches & & .. & . & 1 & 5 & - & & 2 & 12 & 13 & 2 & 56 \\
\hline men & & .. & & & - & 1 & 1 & - & 5 & 3 & 1 & 19 \\
\hline Hips and $b$ & buttocks & .. & & & $=$ & - & - & - & & 4 & - & 5 \\
\hline Thigh .. & .. & .. & & 4 & 5 & 1 & 7 & 3 & 10 & 3 & 2 & 71 \\
\hline & & .. & & & 8 & 2 & 17 & 4 & 10 & 7 & 5 & 89 \\
\hline & . & .. & & 3 & 1 & 5 & 6 & 4 & 18 & 11 & 4 & 86 \\
\hline & .. & $\therefore$ & : & 1 & 3 & - & & 2 & 8 & & & 50 \\
\hline & .. & .. & & 5 & 9 & - & 13 & 8 & 32 & 24 & 4 & 140 \\
\hline ulder & . & . & & 13 & 6 & - & 6 & 1 & 13 & 4 & 1 & 4 \\
\hline & .. & .. & & 1. & 5 & 1 & 6 & 1 & 8 & 7 & 2 & 4 \\
\hline w .. & .. & .. & & 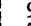 & $\begin{array}{l}9 \\
9\end{array}$ & 3 & 11 & 2 & 5 & 2 & - & \\
\hline & & & & & 2 & - & 5 & - & 5 & 6 & 2 & 27 \\
\hline & & & & 6 & 18 & 2 & 15 & 3 & 12 & 19 & 4 & 124 \\
\hline & $\cdots$ & $\therefore$ & & 11 & & 6 & 56 & 7 & 34: & 48 & 5 & 299 \\
\hline & e & por & & & & & & & & & & \\
\hline
\end{tabular}

